УДК 629.113

UDC 629.113

Сахно $^{1}$ В.П., Стельмащук ${ }^{2}$ В.В., Онищук ${ }^{2}$ В.П. Попелиш ${ }^{1}$ Д.М., Томчук ${ }^{1}$ С.М.

${ }^{1}$ Національний транспортний університет

2 Луиьький наиіональний технічний університет

\title{
ДО ПИТАННЯ ЩОДО ДИНАМІЧНОГО СПОСОБУ УПРАВЛІННЯ АВТОМОБІЛЕМ
}

\begin{abstract}
Показано, що двовісні автомобілі з усіма керованими колесами (4WS) мають переваги над традиційними двоколісними системами керування (2WS). У системах 4WS можуть бути використані кінематичний і динамічний способи повороту. Для реалізації криволінійного руху динамічним способом повинно забезпечуватися певне співвідношення кутових швидкостей коліс різних бортів машини або певне співвідношення крутних моментів, що підводяться до коліс відстаючого та забігаючого бортів. Визначені основні параметри криволінійного руху за динамічного способу повороту. Встановлено, що при фіксованій швидкості повороту автомобіля за більшого моменту на внутрішньому колесі задньої осі поліпшується маневреність автомобіля, а на зовнішньому колесі - стійкість його руху.

Ключові слова: автомобіль, всеколісне керування, керовані колеса. момент, кут повороту, маневреність, стійкість.
\end{abstract}

\section{ВСТУП}

На сучасному етапі активізувались дослідження та розробки, направлені на підвищення активної безпеки автомобілів, і зокрема стійкості та керованості. Як один з напрямків цих досліджень виступає схема всеколісного керування.

Про зацікавленість цим напрямком таких світових флагманів автомобілебудування як Honda, Toyota, Mazda, Nissan, General Motors, Renault, BMW свідчить поточний випуск ними легкових автомобілів з все колісним керуванням (4WS).

Опираючись на досвід використання автомобілів 4WS можна 3 впевненістю відмітити їх переваги над традиційними двоколісними системами керування (2WS). Вони виражаються не тільки в значному підвищенні маневреності автомобіля, а й у таких важливих показниках безпеки руху як стійкість та керованість транспортного засобу на великих швидкостях.

Система всеколісного керування може працювати у трьох режимах:

- у 2WS режимі відбувається керування тільки передніми колесами (як на класичних автомобілях);

- у 4WS режимі, при невеликих швидкостях, задні колеса повертаються у протилежному напрямку щодо повороту передніх коліс, що допомагає транспортному засобу здійснювати повороти зі значно меншим радіусом;

- у 4WS режимі, при високих швидкостях, задні колеса повертаються в тому ж самому напрямку, що і передні, скорочуючи "відхилення від курсу" транспортного засобу.

Поворот задніх коліс у ту ж сторону, що і передніх, дозволяє зберегти напрямок і швидкість руху центра мас автомобіля, але значно збільшити миттєвий радіус повороту. При цьому зменшуються бічні сили i, як наслідок, підвищується курсова стійкість автомобіля та поліпшується керованість при проходженні поворотів на великих швидкостях.

При русі на малій швидкості задні колеса повертаються в протифазі з передніми, і миттєвий радіус повороту зменшується.

По мірі розвитку всеколісного керування змінювався підхід до принципів керування. Так, якщо спочатку основним критерієм було збереження оптимального співвідношення в кутах повороту передніх і задніх коліс, то пізніше поворот задніх коліс забезпечувався за рівнем поперечних прискорень кузова або кутової швидкості повороту кузова навколо вертикальної осі.

Проте витрати на додаткове устаткування всеколісного керування досить значні. Зменшення у Мітцубіші радіуса повороту на $20 \%$ не виправдовує витрачених на це коштів. Це також можна віднести і до розробок компанії Ніссан (Nissan Motor Co., Ltd.), яка у 1989 році представила нову практичну систему керування для 4WS транспортних засобів. Система HICAS (High Capacity Actively controlled Suspension) забезпечувала процес керування при коректуванні кута повороту задніх керованих коліс у відповідності зі швидкістю транспортного засобу та реактивною силою на передніх колесах. Але, як відзначалося в той час, застосовувати активне керування задніми колесами для підвищення безпеки руху було економічно не вигідно [1]. 


\section{АНАЛІЗ ЛІТЕРАТУРНИХ ДЖЕРЕЛ ТА ПОСТАНОВКА ПРОБЛЕМИ}

Усі дослідження і розробки автомобілів 4WS можна розділити на три основних напрямки. Перший з них, це пошук технологічної системи керування, здатної задовольнити найвищі вимоги щодо керованості та стійкості автомобіля; другий - це розробка і впровадження інтелектуальних систем, які у змозі враховувати велику кількість факторів, що впливають на керованість та стійкість руху автомобіля, і на їх основі корегувати параметри його руху; третій - це кооперація між собою факторів, що впливають на керованість та стійкість руху автомобіля.

На сьогодні можна виділити два характерних напрямки розвитку систем підвищення керованості та стійкості руху автомобілів. Перший з них - це застосування систем, що впливають на автомобіль методом блокування його коліс, другий - це застосування систем, що впливають на параметри руху автомобіля за допомогою керування його колесами.

До першого напрямку відносять:

- антиблокувальну систему ABS (Antilock brake system);

- антиковзаючу систему ASR (Antriebs-Schlupf-Regelung);

- систему електронного блокування диференціала EDS (Elektronische

Differentialsperre);

- електронну програму стабілізації ESP (Elektronisches Stabilitats Programm) [1].

До другого напрямку відносять підрулюючі підвіски (еластокінематичні підвіски) та систему всеколісного керування 4WS (For-wheel-steered - автомобіль керований 4-ма колесами), яка призначена для керування колесами задньої осі за визначеним законом у залежності від керуючого впливу водія на передні керовані колеса [2].

По мірі розвитку систем управління 4WS змінювався підхід до принципів керування i, якщо спочатку основним критерієм було забезпечення оптимального співвідношення в кутах повороту передніх і задніх коліс автомобіля, то останнім часом поворот задніх коліс забезпечується за рівнем поперечних прискорень кузова або кутової швидкості повороту кузова навколо вертикальної осі.

Найбільших успіхів у рішенні даної проблеми стосовно легкових автомобілів досягли японські дослідники, що за останні десять-дванадцять років пройшли шлях від найпростішого керування 3 постійним коефіцієнтом у залежностях для кута повороту задніх коліс, розрахованих на простих лінеаризованих моделях і перевірених, як правило, на макетах до випуску серійних автомобілів і автопоїздів із всеколісним керуванням, що забезпечують параметри руху автомобіля близькі до бажаних. Проте, дотепер продовжується полеміка про вид функціональної залежності і чинниках, що необхідно враховувати при виборі закону керування задніми колесами автомобіля й автопоїзда [2-4]. Єдине в чому сходяться всі дослідники, так це те, що при малих кутах повороту рульового колеса від середнього положення поворот автомобіля забезпечується за рахунок повороту передніх і задніх коліс в одну сторону, а при великих кутах повороту рульового колеса -за рахунок повороту передніх i задніх коліс у різні сторони.

У ряді досліджень основним критерієм оцінки ефективності способу керування приймається кут бічного відведення (в англомовній літературі slip angles»-кут бічного ковзання) [5] і ін.

В ідеальному випадку кут повороту задніх коліс повинний рівнятися куту відведення центру мас автомобіля, 3 тим щоб сумарний кут відведення дорівнював нулю. Цього можна домогтися, використовуючи в системі керування поворотом задніх коліс ЕОМ. В ЕОМ закладені, як правило, визначені параметри, наприклад, залежності кутів повороту передніх і задніх коліс при різноманітних швидкостях руху, що враховують бічні прискорення кузова автомобіля при повороті. ЕОМ підраховує в кожний момент руху значення кутового прискорення повороту кузова автомобіля в горизонтальній площині, що порівнюється з припустимим для даної швидкості (при цьому сумарний кут відведення близький до нуля) і за результатами порівняння визначається кут повороту задніх коліс.

Заслуговують на увагу дослідження, проведені фірмою Toyota [6]. Для проведеного на цій фірмі аналізу використовувалася двомірна плоска модель автомобіля. В системі активного контролю в якості зворотного зв'язку прийнята кутова швидкість повороту автомобіля навколо вертикальної осі, що вимірюється з високою точністю. Завдяки введенню другого рульового приводу стабілізується рух автомобіля на криволінійних ділянках дороги, а також зменшується радіус повороту і поліпшується маневреність при паркуванні. Проте витрати на додаткове устаткування дуже значні, а переваги такого керування дуже обмежені. Зменшення радіуса повороту автомобіля фірми Mitsubishi на 20\% не виправдує витрачених на це коштів [7]. Це відноситься також і до автомобілів Nissan, на яких встановлена система HJCAS, необхідна для поліпшення стійкості автомобіля при різкій зміні напрямку руху. Застосовувати активне керування задніми колесами для підвищення безпеки 
автомобіля, як відзначається у названій роботі, економічно невигідно, тобто вирішення проблеми підвищення маневреності і стійкості руху автомобіля слід шукати в удосконаленні робіт першого напрямку, коли для управління автомобілем можна залучити системи, що впливають на автомобіль методом блокування його коліс або різними за величиною, а то і напрямком, моментами на колесах лівого і правого бортів автомобіля.

\section{ЦІЛЬ ТА ЗАДАЧІ ДОСЛІДЖЕННЯ}

Метою роботи є визначення співвідношення в моментах, що підводяться до коліс лівого і правого бортів автомобіля, для поліпшення показників маневреності і стійкості руху. При цьому задачі дослідження визначені у такий спосіб: проаналізувати рівняння динаміки кругового руху машини при комбінованому способі управління поворотом та його складові, що впливають на маневреність і стійкість руху автомобіля,

\section{РЕЗУЛЬТАТИ ДОСЛІДЖЕННЯ}

Поворот колісних машин може здійснюватися трьома основними способами [8,9]:

- зміною кутів між поздовжньою віссю і площинами обертання керованих коліс машини за рахунок їх повороту;

- зміною положення однієї частини машини відносно іншої (зчленовані машини);

- зміною величини швидкостей коліс різних бортів (лівого і правого); цей спосіб аналогічний способу повороту гусеничних машин і називається бортовим або динамічним способом.

Для реалізації криволінійного руху динамічним способом повинно забезпечуватися певне співвідношення кутових швидкостей коліс різних бортів машини [9]. У роботі [10] зазначений спосіб повороту трактується як зміна крутних моментів, що підводяться до коліс відстаючого та забігаючого бортів.

У роботах $[11,12]$ отримані рівняння динаміки кругового руху машини при комбінованому способі управління поворотом

$$
\frac{d \omega}{d t}=\frac{\operatorname{tg} \bar{\alpha}}{1+\frac{b^{2}+i_{z}^{2}}{L^{2}} \operatorname{tg}^{2} \bar{\alpha}} \times\left[\begin{array}{l}
\frac{1}{m \cdot L}\left(\frac{M_{k 1}}{r_{d 1}}+\frac{M_{k 2}}{r_{d 2}}\right)-\frac{f g}{L}-\frac{f h}{L^{3}} \times \\
\times\left(V_{x 1}^{2}+b \frac{d V_{x 1}}{d t}\right) \operatorname{tg}^{2} \bar{\alpha}+\frac{B}{2 L^{2} m} \operatorname{tg} \bar{\alpha} \times \\
\times\left(\frac{M_{k 1}^{\prime \prime}-M_{k 1}^{\prime}}{r_{d 1}}-\frac{M_{k 2}^{\prime \prime}-M_{k 2}^{\prime}}{r_{d 2}}\right)
\end{array}\right],
$$

де $\quad \omega-$ кутова швидкість автомобіля в площині дороги;

$t$ - час;

$\bar{\alpha}-$ середній кут повороту напрямних коліс,

$$
\bar{\alpha}=\frac{1}{2}\left(\alpha^{\prime}+\alpha^{\prime \prime}\right)
$$

$\alpha^{\prime} ; \alpha^{\prime \prime}-$ кути повороту внутрішнього (по відношенню до центру повороту) і зовнішнього напрямних коліс;

$b$ - відстань від задньої осі до проекції центру мас автомобіля на горизонтальну площину;

$m$ - маса автомобіля;

$L$ - поздовжня колісна база автомобіля;

$M_{k 1} ; M_{k 2}$ - сумарні крутні моменти на колесах передньої та задньої осей, відповідно;

$r_{d 1} ; r_{d 2}$ - динамічні радіуси передніх і задніх коліс (допускається приймати $r_{d 1}=r_{d 2}=r_{d}$ );

$f$ - коефіцієнт опору кочення коліс автомобіля;

$h$ - висота центра мас автомобіля;

$i_{z}$ - радіус інерції автомобіля відносно вертикальної вісі; 
$V_{x l}$ - лінійна швидкість автомобіля у напрямку поздовжньої осі;

$M_{k 1}^{\prime} ; M_{k 1}^{\prime \prime}$ - крутні моменти на внутрішньому і зовнішньому передніх колесах;

$M_{k 2}^{\prime} ; M_{k 2}^{\prime \prime}$ - крутні моменти на внутрішньому і зовнішньому задніх колесах.

Із рівняння (1) видно, що різниці крутних моментів на ведучих колесах

$$
\Delta M_{k 1}=M_{k 1}^{\prime \prime}-M_{k 1}^{\prime}
$$

та

$$
\Delta M_{k 2}=M_{k 2}^{\prime \prime}-M_{k 2}^{\prime}
$$

збільшують кутове прискорення $d \omega / d t$ автомобіля у площині дороги. Якщо змінити знак вказаних різниць на протилежний в рівнянні (1), то можна досягнути ситуації при якій $d \omega / d t=0$. Представимо рівняння (1) у вигляді

$$
\begin{aligned}
& \frac{d \omega}{d t}=a(\alpha)[b(M)-c-d(v, \alpha)+k(\alpha, M), \\
& \text { де } a(\alpha)=\frac{\operatorname{tg} \bar{\alpha}}{1+\frac{b^{2}+i_{z}^{2}}{L^{2}} \operatorname{tg}^{2} \bar{\alpha}}, \\
& b(M)=\left[\frac{1}{m \cdot L}\left(\frac{M_{k 1}}{r_{d 1}}+\frac{M_{k 2}}{r_{d 2}}\right)\right], \\
& c=\frac{f g}{L}, \\
& d(v, \alpha)=\left[\frac{f h}{L^{3}} \times\left(V_{x 1}^{2}+b \frac{d V_{x 1}}{d t}\right) \operatorname{tg}^{2} \bar{\alpha}\right], \\
& k(\alpha, M)=\left[\frac{B}{2 L^{2} m} \operatorname{tg} \bar{\alpha} \times\left(\frac{M_{k 1}^{\prime \prime}-M_{k 1}^{\prime}}{r_{d 1}}-\frac{M_{k 2}^{\prime \prime}-M_{k 2}^{\prime}}{r_{d 2}}\right)\right] .
\end{aligned}
$$

При визначенні складових рівняння (5) враховано, що між кутом повороту керованих коліс і швидкістю автомобіля існує залежність [13]

$$
v_{k p y}=\sqrt{\left.\left(\frac{\sqrt{\varphi^{2}-f^{2}}}{\operatorname{tg} \alpha}-f\right) g L \cos \alpha\right)},
$$

де $v_{k p y}$ - критична швидкість по керованості;

$\varphi$ - коефіцієнт зчеплення коліс з дорогою;

$f$ - коефіцієнт опору кочення коліс;

$g$ - прискорення вільного падіння;

$L$-база автомобіля. 
Подальші розрахунки виконаємо за таких вихідних даних:

$b=1,34 \mathrm{м} ; m=2000$ кг; $L=2,67 \mathrm{м} ; r_{d 1}=r_{d 2}=r_{d}=0,265 \mathrm{м} ; f=0,02 ; h=0,8 \mathrm{м} ;-$ висота центра мас автомобіля; $i_{z}^{2}=1,47 \mathrm{M}^{2}$.

Оскільки між швидкістю по керованості і кутом повороту керованих коліс існує певна залежність (7) у подальшому у всіх розрахунках використовувалися відповідні значення швидкості $v_{\mathrm{x}}$ і кута повороту керованих коліс $\alpha$.

На рис. 1-4 наведені результати розрахунку складових рівняння (5) для різних значень кута повороту керованих коліс автомобіля, швидкості руху і прискорення, а також конструктивних параметрів автомобіля.

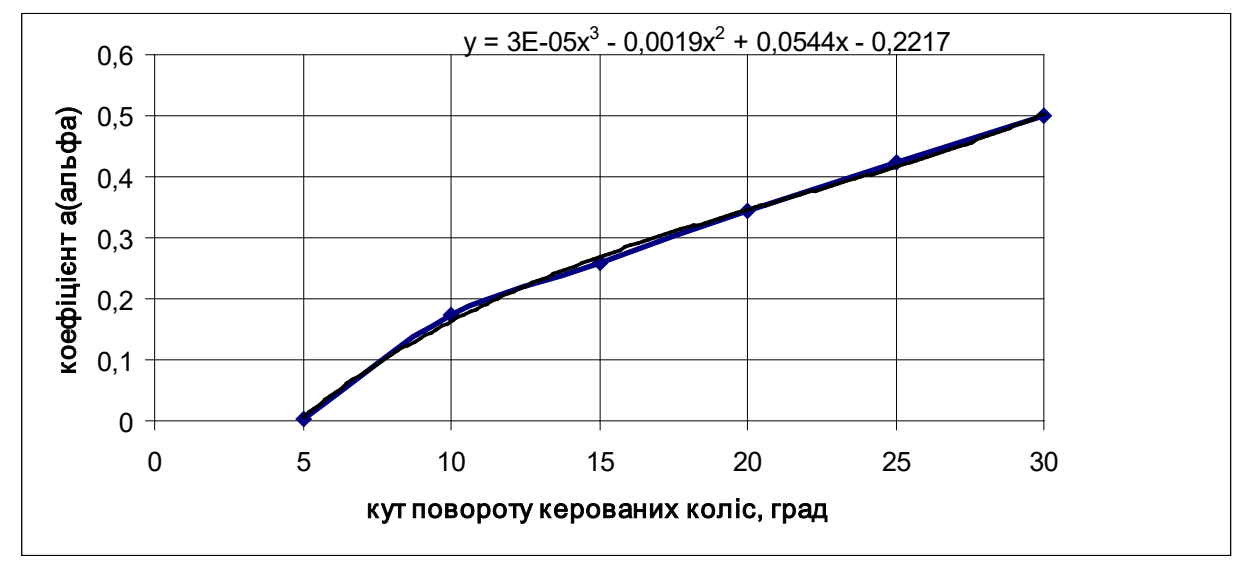

Рисунок 1 - Залежність складової $a(\alpha)$ від кута повороту керованих коліс

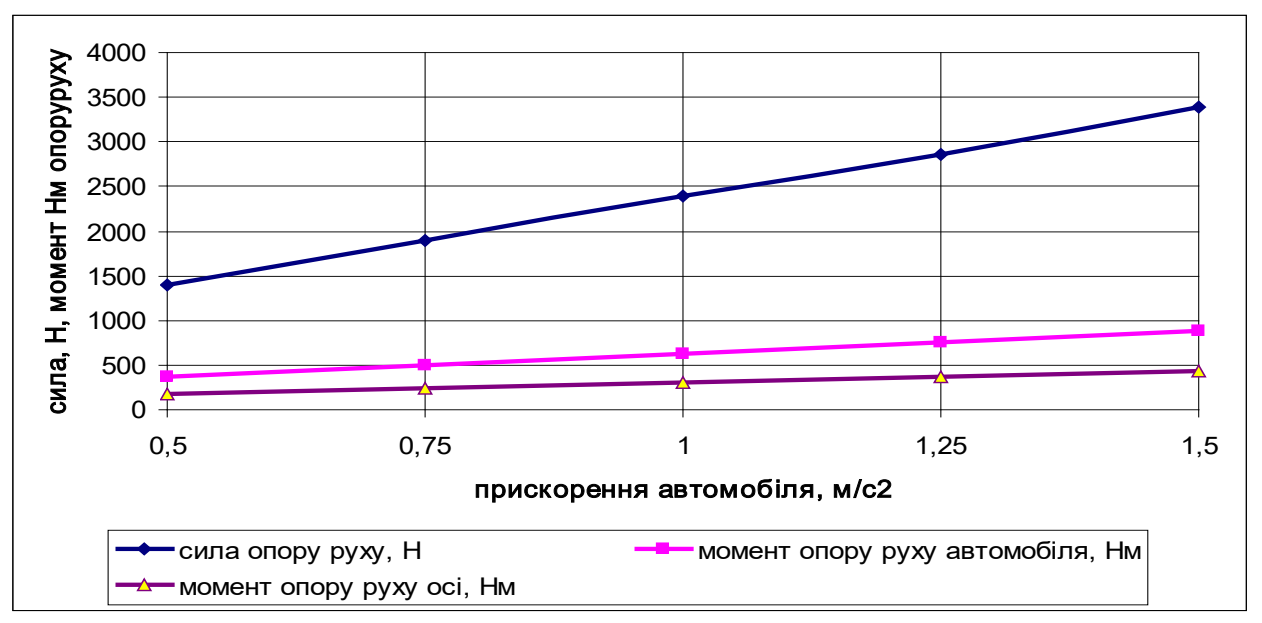

Рисунок 2 - Залежність сили і моменту опору руху від прискорення автомобіля

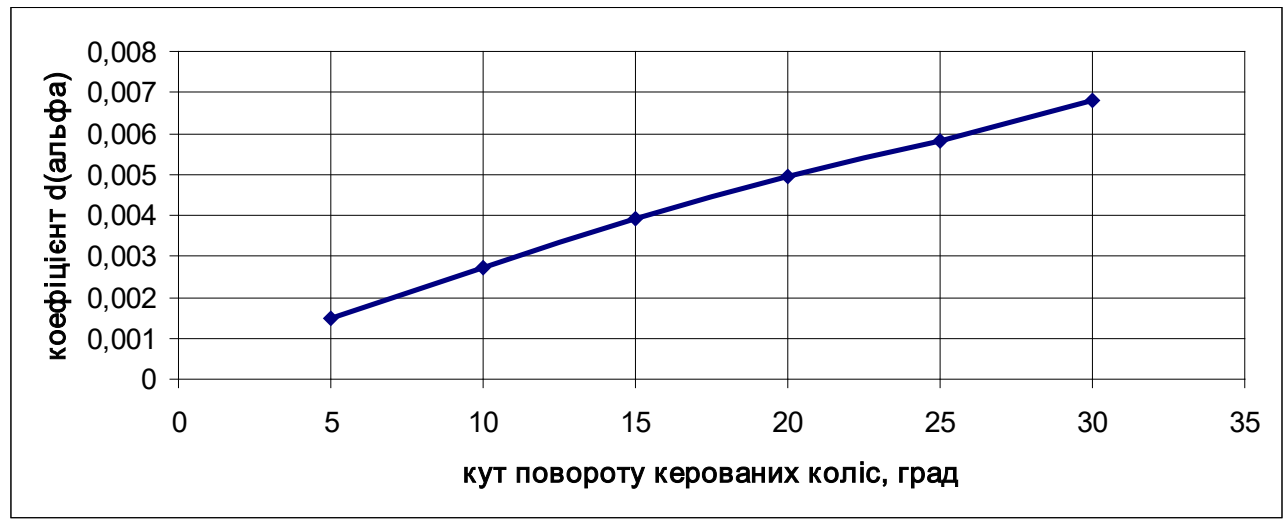

Рисунок 3 - Залежність складової $d$ (альфа) від кута повороту керованих коліс 


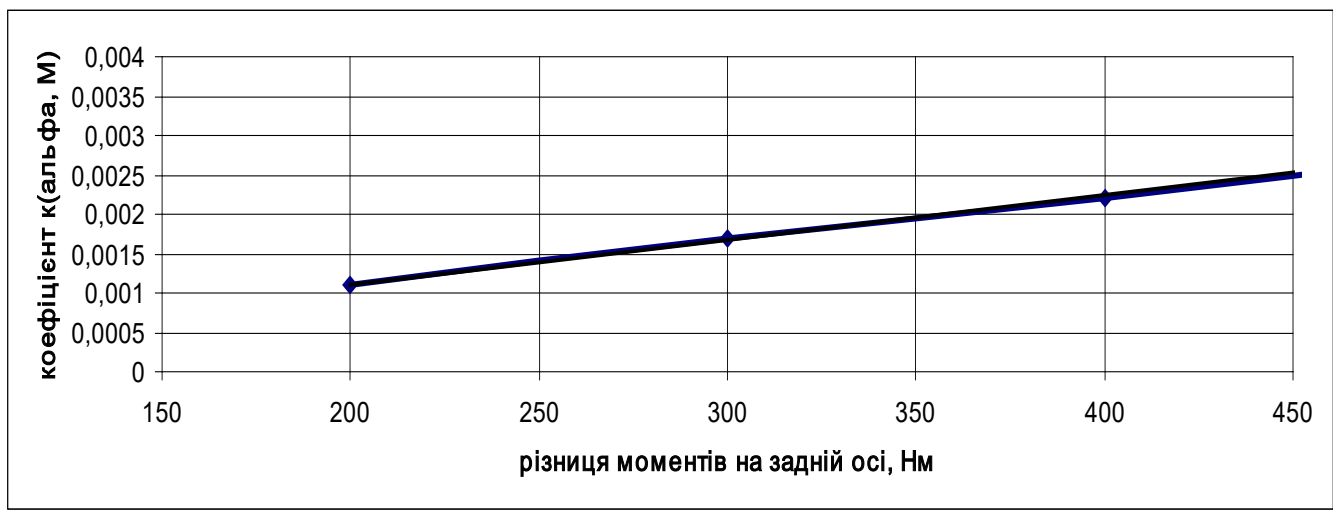

Рисунок 4 - Залежність складової k(альфа) від різниці моментів на колесах задньої осі автомобіля

На рис. 5 наведена залежність кутового прискорення від параметрів руху і конструктивних параметрів автомобіля. При цьому значення окремих складових рівняння (5) приймалися із рис. 1-4.

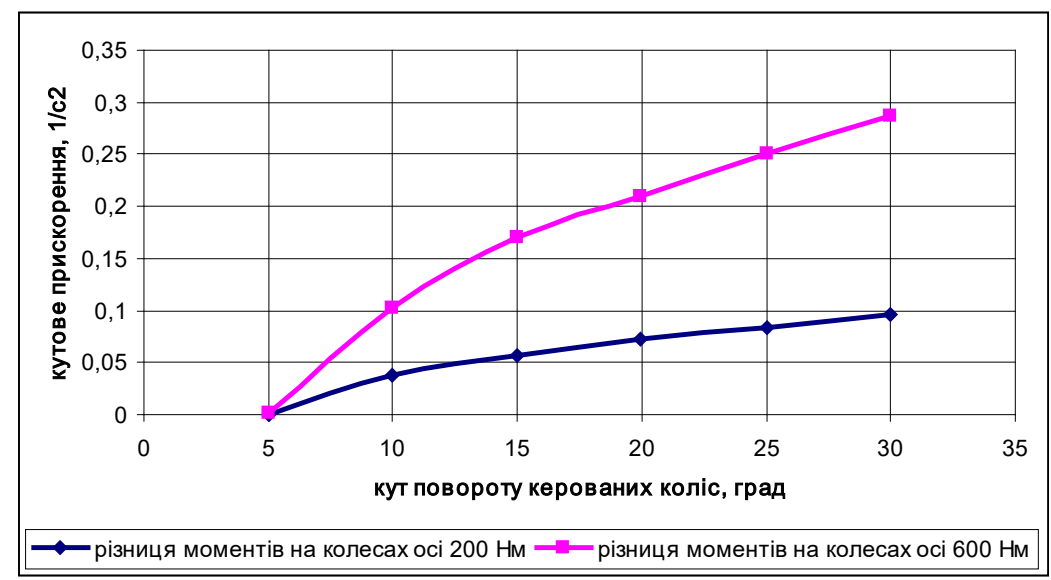

Рисунок 5 - Залежність кутового прискорення автомобіля від кута повороту керованих коліс і різниці моментів на колесах його задньої осі

Як слідує з рис.5, кутове прискорення автомобіля за інших сталих умов суттєво залежить від різниці моментів на колесах осі. Тому важливим виявити плив різниці моментів на колесах осі на показники маневреності автомобіля. Для цього приймемо, що кутове прискорення автомобіля $\frac{d \omega}{d t}=0$ і лінійне прискорення (вздовж осі $x) \frac{d v_{x}}{d t}=0$. Тоді отримаємо:

$$
a(\alpha)[b(M)-c-d(v, \alpha)+k(\alpha, M)=0
$$

Оскільки $a(\alpha) \neq 0$, то

$$
[b(M)-c-d(v, \alpha)+k(\alpha, M)=0
$$

Розв'яжемо рівняння (9) відносно $\alpha$. При цьому врахуємо, що при усталеному русі складові

рівняння (5) $b(\mathrm{M})$ і $c$ рівні між собою, тобто $b(M)=\left[\frac{1}{m \cdot L}\left(\frac{M_{k 1}}{r_{d 1}}+\frac{M_{k 2}}{r_{d 2}}\right)\right]=c=\frac{f g}{L}$.

За цієї умови $d(v, \alpha)=k(\alpha, M)$. 
На рис. 6 представлена залежність різниці крутних моментів на колесах задньої осі автомобіля ідентичної куту повороту керованих коліс автомобіля, при цьому враховувалося співвідношення між критичною швидкістю руху автомобіля і кутом повороту керованих коліс.

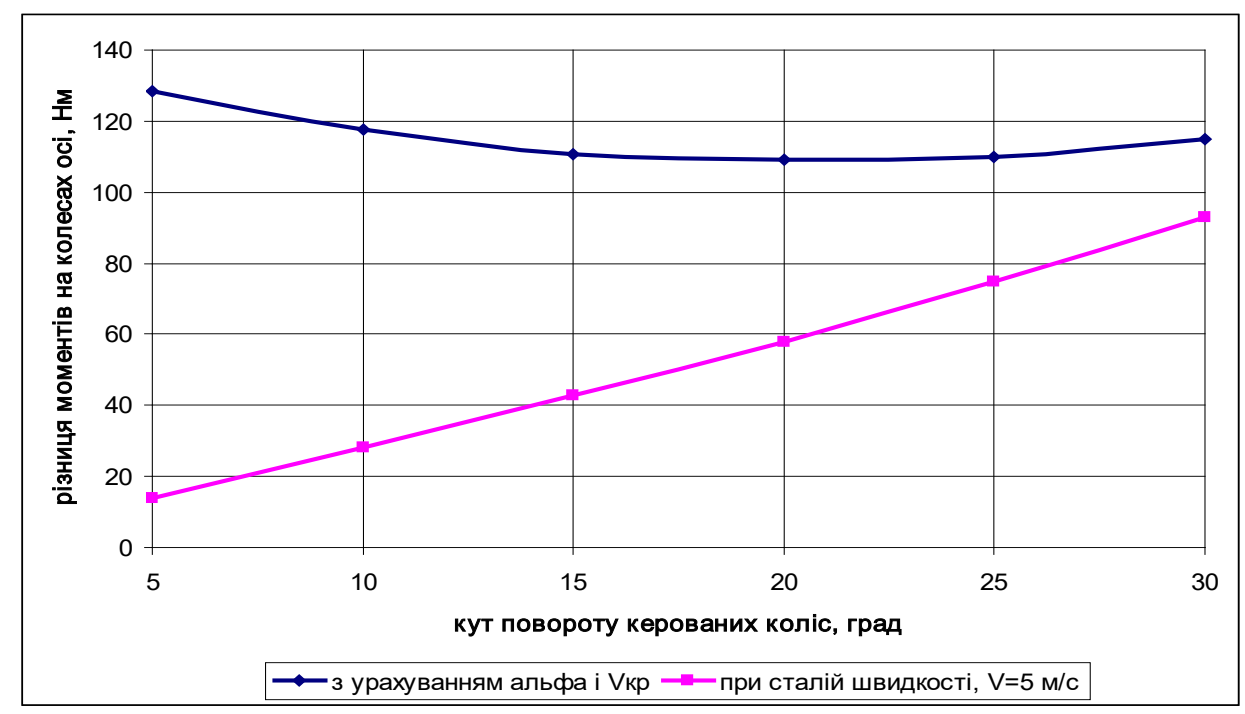

Рисунок 6 - Залежність співвідношення між кутом повороту керованих коліс і різницею моментів на колесах задньої осі автомобіля

Аналіз рис. 6 показує, що при фіксованій швидкості повороту автомобіля зі збільшенням кута повороту його керованих коліс різниця крутних моментів на колесах задньої осі зростає майже пропорційно зміні тангенса кута альфа. При цьому збільшення моменту на внутрішньому колесі задньої осі призводить до зменшення радіусу повороту автомобіля (поліпшується маневреність) i навпаки - збільшення моменту на зовнішньому колесі призводить до руху «крабом» автомобіля (поліпшується стійкість).

ОБГОВОРЕННЯ РЕЗУЛЬТАТІВ ДОСЛІДЖЕННЯ. Отримані залежності щодо зміни показників маневреності і стійкості руху за динамічного способу повороту. Разом з тим, урахування зміни кута повороту керованих коліс і критичної швидкості по керованості дає дещо інший результат, за якого існує мінімум різниці крутних моментів на колесах задньої осі. Пояснюється це тим, що зміна кута повороту керованих коліс і критичної швидкості по керованості з різною інтенсивністю впливають на величину різниці крутних моментів на колесах задньої осі автомобіля.

ВИСНОВКИ. Показано, що автомобілі 4WS мають переваги над традиційними двоколісними системами керування (2WS). У системах 4WS можуть бути використані кінематичний і динамічний способи повороту. Встановлено, що за динамічного способу повороту при фіксованій швидкості повороту автомобіля, зі збільшенням кута повороту його керованих коліс різниця крутних моментів на колесах задньої осі зростає майже пропорційно зміні тангенса кута альфа. При цьому збільшення моменту на внутрішньому колесі задньої осі призводить до зменшення радіусу повороту автомобіля (поліпшується маневреність) і навпаки - збільшення моменту на зовнішньому колесі призводить до руху «крабом» автомобіля (поліпшується стійкість).

\section{ПЕРЕЛІК ДЖЕРЕЛ ПОСИЛАННЯ}

1. Автомобілі. Всеколісне керування: Монографія /В.П.Сахно, О.В.Григорашенко, А.В.Вакуліч, О.М.Тімков, Д.М.Ященко - К.:НТУ, 2013. - 180 с.

2. Рулевое управление. Р.Ж. Автомобилестроение. 1985. № 4А, 4А535 П. - С.3-12.

3. Способ регулирования угла поворота задних колес во всеколесном рулевом управлении. Р.Ж. Автомобилестроение. 1989. №12А, 12 А453 П. - С.5-17.

4. Rear wheel steering device for a vehicle. Kanasawa Hirotaka, и др. Masda Motor Corp.-N 466543 Заявл. 17.01.90. Опубл. 04.06.91. Приор. 18.01.89. № 1- (Япония). МКИ 180/140.

5.Furleigh D.D., Vanderploeg M. J., Oh C.Y. Multiple steared axles for reducing the rollover risksof heavy articulated trucks //SAE techn. Pap. Ser. -1988.-N881866.-C. 1-10.

6. Aktive Control Strategy for Improved Hadling and stability /Yamoto Masaki //SAE Techn. Pap.Ser.-1991 №911902.-C.21-28. 
7.Die neuen Achsenmachte. Vierradlenkung - Fortschrift oder Spielereiy, Mot. und Sport”, 1986, №3, $66-70$

8. Бобошко А.А. Нетрадиционные способы поворота колесных машин. - Харьков: Изд-во ХНАДУ, 2006. - $172 \mathrm{c}$.

9. Чайковский И. П., Саломатин П. А. Рулевое управление автомобилей. - М.: Машиностроение, 1987. - 176 с.

10. Маневренность и тормозные свойства колёсных машин. М.А. Подригало, В.П. Волков, В.И. Кирчатый, А.А. Бобошко. Изд-во ХНАДУ, 2003. 403 с.

11. Подригало М. Підвищення маневреності колісних тракторів. М. Подригало, Л. Греко, А. Бобошко. Машинознавство. Всеукраїнський щомісячний науково-технічний і виробничий журнал, 1999. Вип. №10. С.55 - 58.

12. Фрумкин А. К., Немцов Ю. М., Сыыро Т. В. О зависимости реакций автомобиля от параметров рулевого управления // Автомобильная промышленность. - 1975. - № 6. - c. 11-13.

13. Смирнов Г. А. Теория движения колесных машин.- М.: Машиностроение, 1990. -352 с.

\section{REFERENCES}

1. Cars. All-wheel management: Monograph / V.P.Sakhno, A.V. Grigorashenko, A.V.Vakulich, A.M.Timkov, D.M.Yashchenko - K.: NTU, 2013. - 180 p.

2. Steering. R.J. Automotive. 1985. No. 4A, 4A535 P. - P.3-12.

3. A method of adjusting the angle of rotation of the rear wheels in all-wheel steering. R.J. Automotive. 1989. №12A, 12 A453 P. - P.5-17.

4. Rear wheel steering device for a vehicle. Kanasawa Hirotaka, и др. Masda Motor Corp.-N 466543 Заявл. 17.01.90. Опубл. 04.06.91. Приор. 18.01.89. № 1-(Япония). МКИ 180/140.

5.Furleigh D.D., Vanderploeg M. J., Oh C.Y. Multiple steared axles for reducing the rollover risksof heavy articulated trucks //SAE techn. Pap. Ser. -1988.-N881866.-C. 1-10.

6. Aktive Control Strategy for Improved Hadling and stability /Yamoto Masaki //SAE Techn. Pap.Ser.-1991 №911902.-C.21-28. $66-70$

7.Die neuen Achsenmachte. Vierradlenkung - Fortschrift oder Spielereiy, Mot. und Sport”, 1986, №3,

8. Boboshko AA Non-traditional ways of turning wheeled vehicles. - Kharkov: KhNADU Publishing House, 2006. - 172 p.

9. Tchaikovsky I.P.,Salomatin P.A. Steering of cars.-M.:Mechanical Engineering,1987.-176

p.

10. Maneuverability and brake properties of wheeled vehicles/ M.A. Podrigalo, V.P. Volkov, V.I. Kirchaty, A.A. Boboshko. Kharkov: KhNADU Publishing House, 2003. 403 p.

11. Podrigalo M.A. Increasing the maneuverability of wheeled tractors/ M.Podrigalo, L. Greco, A. Boboshko. Mechanical Science. All-Ukrainian monthly scientific and technical and production journal, 1999. Iss. №10. P.55 - 58.

12. A.K/ Frumkin, Yu. M. Nemtsov, and T. Syyro. On the dependence of the reactions of the car on the steering parameters // Automotive Industry. - 1975. - № 6. - p.11-13.

13. G.A. Smirnov. The theory of motion of wheeled machines. - $M$ : Mechanical Engineering, 1990. - 352 p.

V. Sakhno, V. Stelmashchuk, V. Onyshchuk, D.Popeluch, S.Tomchyk To question on dynamic management of cars

Turning wheeled cars can be done in three main ways, namely by changing the angles between the longitudinal axis and the plane of rotation of the steered wheels of the machine due to their rotation (kinematic method), changing the position of one part of the machine relative to another (articulated machines), changing the magnitude of the speeds of the wheels left and right). The latter method is similar to the method of rotating tracked vehicles and is called the onboard or dynamic method. Any of the above methods can be used in all-wheel drive (4WS).

To realize curvilinear movement in a dynamic way, a certain ratio of the angular velocities of the wheels of the different sides of the machine must be ensured. In this case, all-wheel-drive (4WS) double-axles have advantages over traditional two-wheel-drive (2WS) systems. It is 
established that the dynamic method of rotation at a fixed speed of rotation increase of torque on the inner wheel of the rear axle leads to a decrease in the radius of rotation of the car (improved maneuverability) and vice versa - an increase of torque on the outer wheel leads to the movement of the "crab" of the car (improves). However, taking into account the change in the steering angle of the steered wheels and the critical steering speed gives a slightly different result, with a minimum difference of torque on the rear axle wheels. This is explained by the fact that the change in the steering angle of the steered wheels and the critical speed of control with different intensity affect the amount of torque difference on the wheels of the rear axle of the car.

Keywords: car, all-wheel drive, driven wheels. moment, angle of rotation, maneuverability, stability.

САХНО Володимир Прохорович, доктор технічних наук, професор, завідувач кафедри автомобілів, Національний транспортний університет, svp_40@ukr.net https://orcid.org/0000-00025144-7131

СТЕЛЬМАЩУК Валерій Віталійович, кандидат технічних наук, доцент кафедри автомобілів і транспортних технологій Луцького національного технічного університету, e-mail: Val.stelmashchuk@gmail.com.https://orcid.org/0000-0003-3813-3143.

ОНИЩУК Василь Петрович, кандидат технічних наук, доцент кафедри автомобілів i транспортних технологій, Луцький національний технічний університет, e-mail: Vasyl.Onyshchuk@lutsk-ntu.com.ua, https://orcid.org/0000-0002-5316-408X

ПОПЕЛИШ Денис Михайлович, аспірант кафедри автомобілів, Національний транспортний університет, https://orcid.org/0000-0001-9506-6421

ТОМЧУК Сергій Миколайович, аспірант кафедри автомобілів, Національний транспортний університет, https://orcid.org/0000-0001-5963-556X

\section{AUTHORS:}

Volodymyr SAKHNO, Doctor of Science in Engineering, Professor, Head of Automobiles Department, National Transport University, e-mail: sakhno@ntu.edu.ua https://orcid.org/0000-0002-5144-7131

Valery STELMASHCHUK, Ph.D in Engeneering, associate professor of automobiles and transport technologies department, Lutsk National Technical University, e-mail: Val.stelmashchuk@gmail.com. https://orcid.org/0000-0003-3813-3143.

Vasyl ONYSHCHUK, $\mathrm{PhD}$ in Engineering, associate professor of Automobiles and Transport Technologies department, Lutsk National Technical University e-mail: Vasyl.Onyshchuk@lutsk-ntu.com.ua, https://orcid.org/0000-0002-5316-408X

Denis POPELYSH, magistr of transport, postgradiate student of Automobiles Department, National Transport University, popelish@ukr.net https://orcid.org/0000-0001-9506-6421

Serhii TOMCHUK, magistr of transport, postgradiate student of Automobiles Department, National Transport University, stomchuk34@gmail.com https://orcid.org/0000-0001-5963-556X 